\title{
O MIGRANTE
}
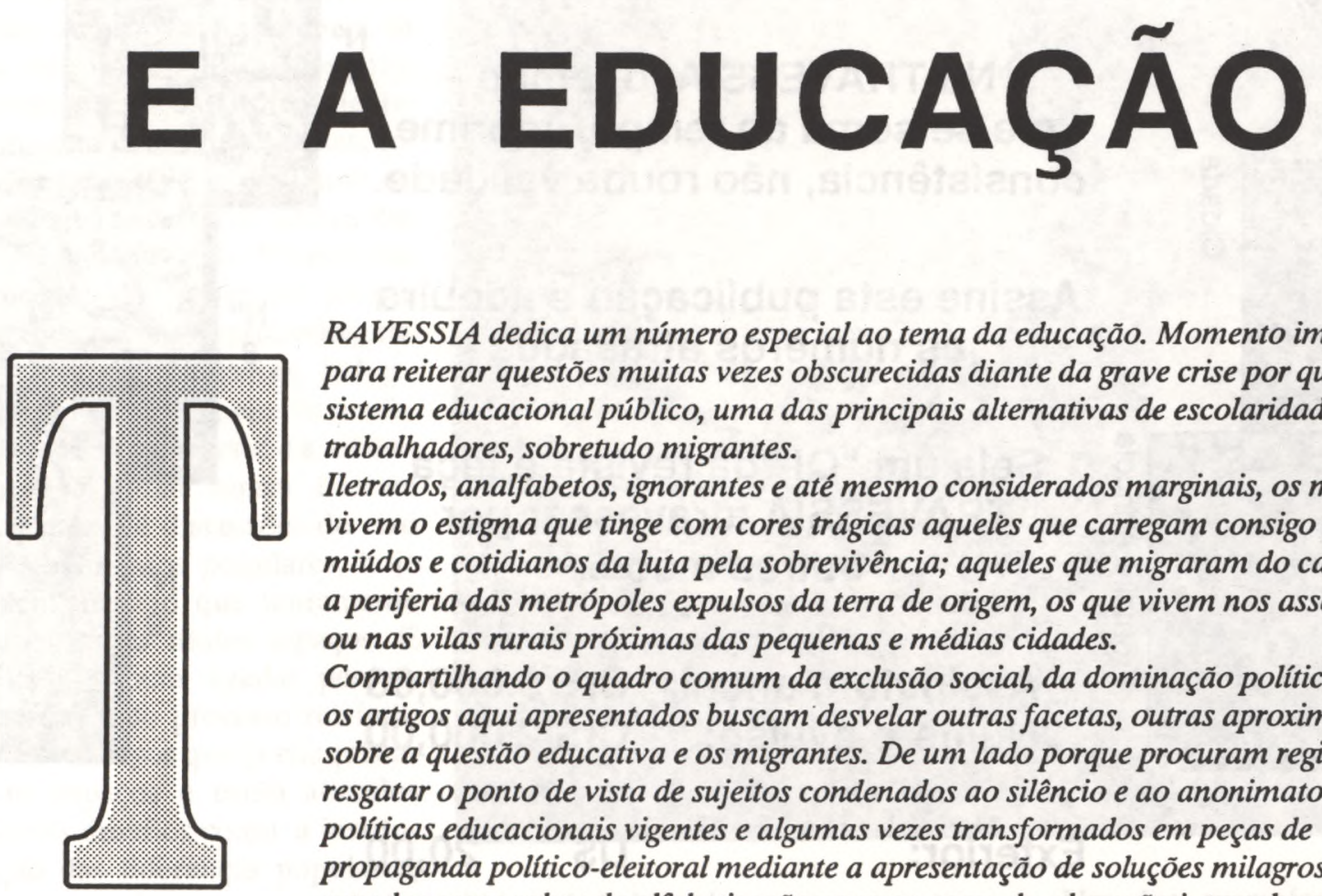

RAVESSLA dedica um número especial ao tema da educação. Momento importante para reiterar questões muitas vezes obscurecidas diante da grave crise por que passa o sistema educacional público, uma das principais alternativas de escolaridade para os trabalhadores, sobretudo migrantes.

Iletrados, analfabetos, ignorantes e até mesmo considerados marginais, os migrantes vivem o estigma que tinge com cores trágicas aqueles que carregam consigo os dramas miúdos e cotidianos da luta pela sobrevivência; aqueles que migraram do campo para a periferia das metrópoles expulsos da terra de origem, os que vivem nos assentamentos ou nas vilas rurais próximas das pequenas e médias cidades.

Compartilhando o quadro comum da exclusão social, da dominação político-cultural os artigos aqui apresentados buscam desvelar outras facetas, outras aproximações sobre a questão educativa e os migrantes. De um lado porque procuram registrar e resgatar o ponto de vista de sujeitos condenados ao silêncio e ao anonimato nas políticas educacionais vigentes e algumas vezes transformados em peças de propaganda político-eleitoral mediante a apresentação de soluções milagrosas como as grandes campanhas de alfabetização ou promessas de educação integral traduzidas em mecanismos de caráter assistencial. De outro porque mostram o quanto são múltiplos e diferençados os espaços educativos; as aspirações, a recusa da opressão, o sonho, as práticas, as experiências e projetos pedagógicos estão presentes na vida de cada um dos que migraram, nos seus grupos primários, nas escolas e nos movimentos que buscam constituir novas identidades e novos sujeitos.

Há outras dimensões educativas e projetos que precisam ser desvendados e este número propicia um momento importante para a reflexão. Trata-se do desencontro entre as teorias e os processos sociais concretos. Reconhecer as práticas educativas que se dão nos movimentos e recuperar criticamente a importância da escola para os protagonistas da subalternidade têm constituído desafios ainda não totalmente superados. Os modelos teóricos, muitas vezes carregados de preconceitos e orientaçöes apriorísticas, criaram dicotomias entre a educação formal e a educação popular, entre o campo e a cidade, instrumentalizaram movimentos sociais, mitificaram a escola ou a consideraram mero mecanismo difusor da ideologia e ascensão social. TRAVESSLA busca neste número sugerir que um possível encontro entre teoria e prática concreta exige o resgate, em profundidade, do ponto de vista dos sujeitos que vivem a exclusão, produzem cultura, buscam enriquecer cotidianamente sua experiência educativa e lutam para se apropriar de um mundo que lhes é negado. Este resgate dos processos educativos em sua diversidade, reconhecendo a complexidade dos sujeitos e suas representações, certamente desvelará que a educação integra projetos e gesta utopias, alimenta lutas miúdas e obscuras que adquirem sua importância porque tecem, também, no seu anonimato, os fios da história.

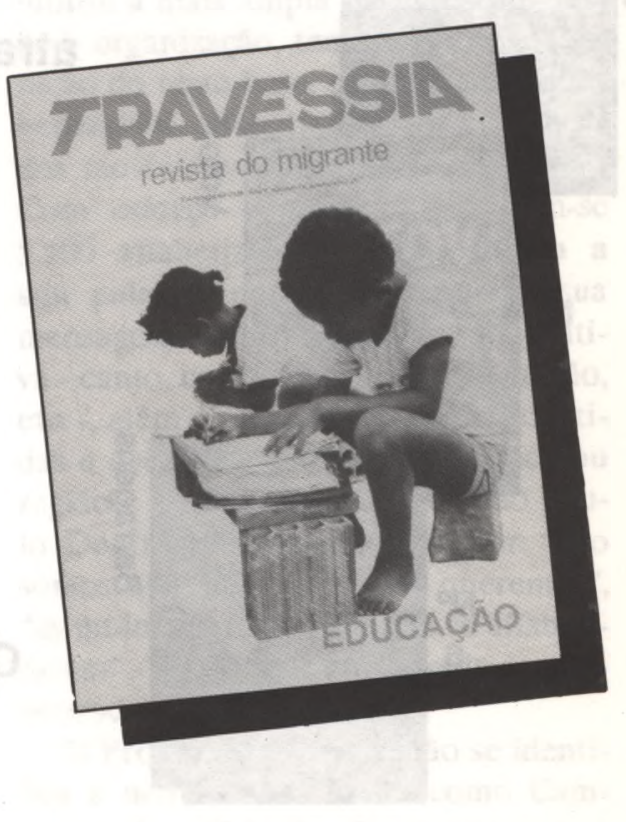

